\title{
STATUS HUKUM TANAH WARGA YANG BERMUKIM DI WILAYAH PESISIR PERBATASAN KABUPATEN NUNUKAN PROVINSI KALIMANTAN UTARA
}

\author{
Sulaiman \\ Fakultas Hukum Universitas Borneo \\ Pantai Amal, Tarakan Timur \\ Kota Tarakan, Kalimantan Utara \\ Email :sulaiman.hukum@gmail.com \\ Zulvia Makka \\ Fakultas Hukum Universitas Borneo \\ Pantai Amal, Tarakan Timur \\ Kota Tarakan, Kalimantan Utara \\ Email:zulviamakka@gmail.com
}

\begin{abstract}
The province of North Kalimantan is the youngest province in Indonesia, currently located in the north of the island of Borneo. Nunukan Regency is one offive districts / towns in North Kalimantan Province covering an area of 14,263.68 km2. Due to its geography, Nunukan Regency is located in the northernmost region of Kalimantan, which borders directly with neighbouring Sabah-Malaysia. The legal status of land ownership is a written proof that receives legal recognition. All land rights are recorded in the form of National Land Agency (BPN) certificates. The BPN provides landowners with duplicates to avoid future risks, such as: lost, burned or multiple certificates. In Indonesia, land ownership status is governed by the Agrarian Law Act (UUPA) No 5 of 1960 on agricultural principles. Rural residents living in the coastal border region, in particular in the Nunukan sub-district, Nunukan Utara district. Nunukan Regency is a borrowed land used by PT. Inhutani as de facto Business Owner (HGU), on the land of HGU PT. Inhutani at the Nunukan Regency, Nunukan Subdistrict and Nunukan Utara Village are thousands of buildings owned by both the community and the government, most of which have no proof of legal control. The problem of this study is the legal status of land ownership of coastal residents and the policy of local authorities in providing legal solutions. Based on the results of the study, it was found that the legal status of residents living in the coastal perimeter was a right of use, such as PT's Cultivation Rights (HGU) transformation. Inhutani, of which the researchers knew that they had finished their land use rights (HGU) since 2009 extended to 2038. The legal solution for ensuring legal certainty of builders in the country PT. Inhutani was granted the municipality the right to build (HGB) until the rights were bleached because PT. Inhutani is no longer productive and does not produce and produce forest products at Nunukan Utara Village, but only the construction of settlements and thousands of public and government buildings. Legal Status of Land Ownership of Residents of Coastal Borders The legal status of Nunukan District Nunukan is owned by PT in the Nunukan District. Inhutani Legal certainty for builders on the land area of PT. Inhutani is the provision of user rights for buildings (HGB) for builders, provided that a written agreement of PT exists. Inhutani.
\end{abstract}

Key Words: Land Legal Status, Government Policy 


\section{A. PENDAHULUAN}

Tanah adalah karunia dari Tuhan Yang Maha Esa kepada umat manusia di muka bumi. Tanah menjadi kebutuhan dasar manusia. Sejak lahir sampai meninggal dunia, manusia embutuhkan tanah untuk tempat tinggal dan sumber kehidupan. Secara kosmologis, tanah adalah tempat manusia tinggal, tempat bekerja dan hidup, tempat dari mana mereka berasal dan akan kemana pula mereka pergi. Dalam hal ini tanah mempunyai dimensi ekonomi, sosial, kultural politik dan ekologis.

Dalam sejarah peradaban umat manusia, tanah merupakan faktor yang paling utama dalam menentukan produksi setiap fase peradaban. Tanah tidak hanya mempunyai nilai ekonomis tinggi, tetapi juga nilai filosofis, politik, sosial, dan kultural. Tidak mengherankan jika tanah menjadi harta istimewa yang tidak henti-hentinya memicu berbagai masalah sosial yang kompleks dan rumit.

Tanah merupakan bagian dari bumi, yang disebut permukaan bumi. Tanah yang dimaksud disini bukan mengatur tanah dalam segala aspeknya, melainkan hanya mengatur salah satu aspeknya, yaitu tanah dalam pengertian yuridis yang disebut hak. ${ }^{1}$ Pertanahan merupakan masalah yang tidak ada habisnya sepanjang zaman. Oleh karena itu, pada tanggal 24 September 1960, pemerintah kemudian menerbitkan Undang-Undang Nomor 5 Tahun 1960 tentang Peraturan Dasar Pokok-Pokok Agraria dan Ketentuan Konversi yang lebih dikenal sebagai UndangUndang Pokok Agraria (selanjutnya disingkat UUPA). Sumber UUPA ini lahir dari Pasal 33 ayat (3) Undang-Undang Dasar 1945 yang mengatur bahwa "Bumi, air dan kekayaan alam yang terkandung di dalamnya dikuasai oleh Negara dan dipergunakan sebesarbesarnya untuk kemakmuran rakyat". Menyadari nilai dan arti penting tanah, para pendiri Negara Kesatuan Republik Indonesia (NKRI) merumuskan tentang

' Urip Santoso.(2009). Hukum Agraria dan Hak-Hak Atas Tanah, Jakarta: Kencana Prenada Media, hlm.10. tanah dan sumber daya alam secara ringkas tetapi sangat filosofis substansial di dalam Konstitusi, Pasal 33 Ayat (3) Undang-undang Dasar 1945 tersebut, Pada era reformasi seperti sekarang ini masalah pertanahan merupakan masalah yang sangat penting peranannya guna menunjang pembangunan sehingga masalah pertanahan mudah menarik perhatian sebagian orang yang menjadikan masalah pertanahan sebagai sarana atau alat untuk mencapai maksud-maksud tertentu.

Indonesia yang merupakan negara kepulauan (17.508 pulau) dan merupakan negara kepulauan terbesar di dunia yang memiliki garis pantai terpanjang kedua setelah Brasil. Panjang garis pantai mencapai 81.000 $\mathrm{km} 2$ dengan luas laut sekitar 3,1 juta $\mathrm{km} 2$ ( 0,3 juta $\mathrm{km} 2$ perairan teritorial dan 2,8 juta $\mathrm{km} 2$ perairan nusantara) atau $62 \%$ dari luas teritorial Indonesia ${ }^{2}$. Berdasarkan UNCLOS 1982 (United Nations Convention On The Law Of The Sea 1982), Indonesia diberi hak berdaulat (sovereign right) memanfaatkan Zona Ekonomi Eksklusif(ZEE) seluas 2,7 juta km2 yang menyangkut eksplorasi, eksploitasi dan pengelolaan sumber daya hayati dan non hayati, penelitian dan jurisdikasi mendirikan instalasi atau pulau buatan. Selain dari itu Indonesia merupakan negara kepulauan dimana terdiri dari beberapa pulau yang memiliki suku, adat istiadat dan ke-biasaan yang berbeda-beda dalam penguasaan tanah. ${ }^{3}$

Dalam suatu wilayah pesisir terdapat satu atau lebih lingkungan dan sumber daya pesisir. Lingkungan pesisir dapat bersifat alam ataupun buatan. Lingkungan yang bersifat alami yang terdapat di wilayah pesisir antara lain terumbu karang, hutan mangroves, padang lamun, pantai berpasir, formasi pescaprea, formasi baringtonia, laguna dan delta. Sedangkan lingkungan yang bersifat buatan yang terdapat di wilayah pesisir antara lain tambak, sawah pasang surut, kawasan pariwisata, kawasan industri, kawasan agroindustri dan kawasan pemukiman.

\footnotetext{
${ }^{2}$ Rokhmin Dahuri.(2004). Pengelolaan Sumber Daya Wilayah Pesisir Dan Laut Secara Terpadu, Jakarta: Pradnya Paramita, hlm.1-2.

${ }^{3}$ Ibid., hlm.9.
} 
Perencanaan dan pengelolaan wilayah pesisir secara sektoral biasanya berkaitan dengan hanya satu macam pemanfaatan sumber daya atau ruang pesisir oleh satu instansi pemerintah untuk memenuhi tujuan tertentu, seperti perikanan tangkap, tambak, pariwisata, pelabuhan, pemukiman atau industri minyak dan gas. Pengelolaan semacam ini dapat menimbulkan konflik kepentingan antar sektor yang berkepentingan yang melakukan aktivitas pembangunan pada wilayah pesisir.

Pasal 2 ayat (2) UUPA dikemukakan bahwa hak menguasai negara adalah memberikan kewenangan kepada negara untuk mengatur dan menyelenggarakan peruntukan, penggunaan, persediaan dan pemeliharaan bumi, air, dan ruang angkasa. Hak menguasai negara bukanlah berarti negara yang memiliki tanah, tetapi memberikan kewenangan kepada negara sebagai organisasi kekuasaan dari bangsa Indonesia pada tingkatan tertinggi untuk mengatur dan menyelenggarakan peruntukan, penggunaan, persediaan dan pemeliharaan bumi, air, dan ruang angkasa. Selain itu, negara juga memiliki kewenangan untuk menentukan dan mengatur hakhak yang dapat dipunyai atas bumi, air, dan ruang angkasa serta menentukan dan mengatur hubungan-hubungan hukum antar orang-orang dan perbuatan-perbuatan hukum mengenai bumi, air dan ruang angkasa dengan tujuan untuk mencapai sebesarbesarnya kemakmuran rakyat dalam rangka mewujudkan masyarakat yang adil dan makmur.

Kemudian, dalam Pasal 14 ayat (1) UUPA 1960 juga dijelaskan bahwa dalam rangka penerapan paham sosialisme di Indonesia, pemerintah membuat suatu rencana umum mengenai persediaan, peruntukan, dan penggunaan bumi, air, dan ruang angkasa serta kekayaan alam yang terkandung di dalamnya. Wewenang tersebut dengan kata lain adalah wewenang untuk melakukan penataan ruang. Dalam melakukan penataan ruang tersebut, maka wajib memperhatikan asas-asas pengelolaan lingkungan hidup dan asas-asas penataan ruang serta asas-asas lain yang bersangkut paut dengan hal tersebut yang terdapat dalam aturan perundang-undangan lainnya. Dengan berlakunya Undang-Undang Nomor 32 Tahun 2004 tentang Pemerintahan Daerah (terakhir diganti dengan UndangUndang Nomor 23 Tahun 2014 tentang Pemerintahan Daerah) di-mana tiap-tiap daerah memiliki kewenangan penuh atas daerahnya sendiri, maka tiap-tiap kepala daerah mempunyai hak untuk kemudian melakukan penataan ruang.

Penataan ruang bukan hanya mengatur struktur ruang yang ada di wilayah da-ratan saja, tetapi menyangkut seluruh wila-yah kabupaten/kota, termasuk wilayah pesisir yang dimilikinya. Wilayah pesisir memiliki arti strategis karena merupakan wilayah peralihan antara ekosistem darat dan laut. Kekayaan sumber daya pesisir dikuasai oleh negara untuk dikelola sedemikian rupa untuk mewujudkan kesejahteraan masyarakat, memberikan manfaat bagi generasi sekarang tanpa mengorbankan kebutuhan generasi yang akan datang.

Secara umum, banyak masyarakat yang sudah bermukim di wilayah pesisir perbatasan kabupaten nunukan yang tidak mengetahui status hukum tanahnya (legalitas kepemilikannya). Oleh karena itu, perlunya penelitian atau kajian hukum yang harus dilakukan untuk memberikan pemahaman hukum dan kepastian hukum terhadap status tanah (legalitas kepemilikan) warga yang bermukim di wilayah pesisir perbatasan Kabupaten Nunukan Provinsi Kalimantan Utara, Hal ini kemudian berdampak pada perubahan ekosistem pesisir karena masyarakat yang bermukim di wilayah tersebut melakukan eksploitasi terhadap sumber daya pesisir. Namun, selain berdampak negatif, ada pula yang berdampak positif, yakni makin terpeliharanya ekosistem pesisir karena mereka yang bermukim di wilayah tersebut berpandangan bahwa itulah potensi hidup mereka. Disamping itu Tidak berbeda dengan pemilikan dan penguasaan tanah di wilayah daratan (di luar wilayah pesisir), pola pengusaan dan pemilikan tanah 
di wilayah pesisir juga sering mengalami persengketaan. Berdasarkan uraian diatas maka perlu kiranya dilakukan penelitian tentang status kepemilikan tanah warga yang bermukim di wilayah pesisir perbatasan khususnya di kecamatan Nunukan utara kabupaten Nunukan Provinsi Kalimantan Utara, yang daerahnya berbatasan langsung dengan perbatasan wilayah pesisir SabahMalaysia.

Dalam penelitian ini, akan membahas beberapa permasalahan yaitu:

1. Bagaimanastatushukumkepemilikantanah perumahanwargayangbermukimdiwilayah pesisir perbatasan ?

2. Bagaimana bentuk-bentuk kebijakan Pemerintah Daerah dalam penertiban pemanfaatan tanah warga di wilayah pesisir perbatasan?

\section{B. METODE PENELITIAN}

Metode Penelitian hukum yang penulis gunakan dalam penulisan ini adalah jenis penelitian yuridis normatif . Yaitu penelitian hukum yang dilakukan dengan cara meneliti bahan pustaka atau data sekunder. ${ }^{4}$ Penulisan ini menggunakan metode yang sistematik dan terarah dengan menggunakan undang-undang sebagai dasar hukum sekaligus pedoman untuk analisis. Keseluruhan rangkaian kegiatan penulisan pada dasarnya ditujukan pada pengumpulan bahan hukum, kemudian bahan tersebut diolah dan dikaitkan dengan konsep-konsep hukum, dan hasil yang diperoleh dituangkan dalam bentuk pemikiran yuridis.

\section{PEMBAHASAN}

Status Hukum Kepemilikan Tanah Perumahan Warga Yang Bermukim Di Wilayah Pesisir Perbatasan

Tanah perumahan warga yang bermukim di wilayah pesisir di Kabupaten nunukan, Kecamatan Nunukan, Kelurahan Nunukan

${ }^{4}$ Soerjono Soekanto dan Sri Mamudji.(2006). Penelitian Hukum Normatif, Jakarta: PT. Raja Grafindo Persada, hlm.12.
Utara yang langsung berbatasan dengan Sabah-Malaysia. pada awalnya merupakan pengalihan hak - hak atas tanah yang dahulu milik PT. Inhutani. PT (Persero) Inhutani adalah Badan Usaha Milik Negara yang didirikan pada tanggal 12 Nopember 1975 berdasarkan Peraturan Pemerintah Nomor 32 Tahun 1974 yang merupakan hasil likuidasi dari PN. Perhutani Kalimantan Selatan, dan Proyek Khusus Pontianak. Pendirian Perusahaan dikukuhkan dengan Akte Notaris Kartini Mulyadi, S.H. Nomor 77 tanggal 12 Nopember 1975 yang disahkan dalam Daftar Keputusan Menteri Kehakiman RI tanggal 26 Januari 1976 No : YA.5/50/176 dan diumumkan dalam Tambahan Berita Negara RI No : 275/1976. Perubahan Anggaran Dasar Perusahaan dikukuhkan melalui Akte Notaris Nanda Fauz Iwan, S.H. M.Kn No. 13 tanggal 12 Agustus 2008 yang merupakan perubahan dari Akte Notaris Imas Fatimah, SH Nomor : 67 Tahun 1984.

Adapun Kepemilikan Saham PT Inhutani saat ini adalah sebagaimana pada tabel berikut ini :

\begin{tabular}{llccccc}
\hline no & $\begin{array}{c}\text { Pemegang } \\
\text { saham }\end{array}$ & $\begin{array}{c}\text { Jumlah } \\
\text { saham } \\
\text { (lem- } \\
\text { bar) }\end{array}$ & $\begin{array}{c}\text { Nilai } \\
\text { nominal } \\
\text { (x Rp } \\
1.000)\end{array}$ & $\begin{array}{c}\text { Nilai saham } \\
\text { (x Rp 1.000) }\end{array}$ & $\begin{array}{c}\text { Jenis } \\
\text { saham }\end{array}$ & ket \\
\hline 1 & $\begin{array}{l}\text { Negara Re- } \\
\text { publik Indo- } \\
\text { nesia }\end{array}$ & 183.083 & 1.000 & 183.083 .000 & Biasa & $\begin{array}{l}\text { Dise - } \\
\text { tor }\end{array}$ \\
\hline 2 & $\begin{array}{l}\text { S a h a m } \\
\text { dalam } \\
\text { simpanan }\end{array}$ & 216.917 & 1.000 & 216.917 .000 & Biasa & penuh \\
\hline $\begin{array}{l}\Sigma \\
\text { Saham Perseroan }\end{array}$ & & & & & \\
\hline
\end{tabular}

Modal Dasar Perusahaan sebesar Rp 400.000.000.000,- (empat ratus milyar rupiah) merupakan perubahan modal dasar perusahaan sesuai perubahan Anggaran Dasar Perusahaan PT Inhutani II (Persero) yang terakhir dikukuhkan dengan Akte Notaris Nanda Fauz Iwan, SH. M.Kn Nomor 13 tanggal 12 Agustus 2008.

PT Inhutani I berdiri tahun 1973 (PP No 21 Tahun 1972), lanjutan dari PN Perhutani Kalimantan Timur. Areal konsesi seluas 2,2 juta Ha dengan masa konsesi 20 tahun (Periode Pertama) dari tahun 1973 sampai dengan 1993. Pada tahun 2006, PT Inhutani 
I memperoleh perpanjangan prinsip masa konsesi periode kedua yang berlaku hingga 2038. PT. Eksploitasi dan Industri Hutan (PT.INHUTANI I) dibentuk berdasarkan Peraturan Pemerintah Nomor 21 tahun 1972 guna melanjutkan kegiatan PN Perhutani Kalimantan Timur untuk mengelola areal hutan di Propinsi Kalimantan Timur. Anggaran Dasar perusahaan dibuat dihadapan Notaris Soeleman Ardjasasmita, SH dengan Akte nomor 5 tanggal 8 Desember 1973 dan telah dimuat dalam Berita Negara Republik Indonesia tanggal 30 Juli 1974 Nomor 62. Seiring dengan perkembangan usaha Perseroan, Anggaran Dasar telah beberapa kali dilakukan perubahan, dan terakhir diperbaharui berdasar Keputusan Pemegang Saham Perusahaan (Persero) PT INHUTANI I di luar RUPS tentang Perubahan Anggaran Dasar Perusahaan Perseroan (Persero) PT INHUTANI I Nomor : KEP-08/S.MBU/2010 - KEP-01/D4.MBU/2010 dan ditetapkan dengan Akte Notaris Reni Rohaini, SH, MBA Nomor : 23 tanggal 10 Maret 2010 seta telah dicatat dalam data base Sistem Administrasi Badan Hukum Kementerian Hukum dan Hak Asasi Manusia nomor : AHU-0029974. AH.01.09 Tahun 2010 tanggal 21 April 2010.

Berdasarkan status hukumnya tanah dibagi menjadi dua yaitu:

1. Tanah negara yaitu semua tanah yang langsung dikuasai oleh negara.

2. Bukan tanah negara atau disebut tanah hak, yaitu semua tanah yang dikuasai orang atau badan hukum berdasarkan hak tertentu ${ }^{5}$

Ketika seseorang atau badan hukum atau persekutuan hukum mendapat hak atas tanah, maka pada setiap pemegang "hak" mendapatkan perlindungan hukum dari setiap ancaman yang datang kepadanya. Perlindungan itu diberikan oleh sebuah lembaga adat maupun lembaga lain yang dapat memberikan sanksi atas pelanggaran kejahatan terhadap hak atas tanah orang lain. Hal ini dapat dibuktikan dalam implementasi dalam masyarakat diberbagai daerah di

${ }^{5}$ Suhariningsih.(2009). Tanah Terlantar, Jakarta: Prestasi Pusaka, hlm.81.
Indonesia. Namun berhubung hukum tanah di Indonesia menghendaki adanya kepastian hukum (hak atas tanah) yang dibuktikan dengan adanya sertifikat, maka perolehan hak atas tanah dengan cara menurut Hukum Adat seperti dijelaskan diatas menjadi perolehan hak atas tanah tidak terjamin secara formal adanya kepastian "hak"

Karena secara formal tidak ada bukti (administrasi) tetapi secara riil ada pemilik atau pemegang hak atas tanah. Oleh karena itu dari pemahaman konsep, hak yang telah diuraikan diatas maka bukti hak atas tanah berupa surat (sertipikat) memang diperlukan guna mendukung hak atas tanah yang dimiliki seseorang atau badan hukum secara materiil. ${ }^{7}$

Intinya bahwa semua hak penguasaan atas tanah berisi serangkaian wewenang, kewajiban dan atau larangan bagi pemegang haknya untuk berbuat sesuatu mengenai tanah yang di haki. "Sesuatu" yang boleh, wajib dan dilarang untuk diperbuat yang isi hak penguasaan itulah yang menjadi titik tolak pembeda diantara hak-hak penguasaan atas tanah yang diatur dalam hukum tanah. Misal, hak atas tanah yang disebut dalam Pasal 28 dibatasi jangka waktu penggunaan tanahnya. Demikian juga HGB, Hak Tanggungan sebagai hak penguasaan atas tanah, juga berisi kewenangan bagi kreditor untuk berbuat sesuatu mengenai tanah yang dijadikan agunan. Hak penguasaan tanah oleh kreditur bukan untuk dikuasai secara fisik dan digunakan, melainkan untuk menjualnya jika debitur cidera janji dan mengambil dari hasil seluruhnya atau sebagian sebagai pembayaran lunas hutang debitor kepadanya ${ }^{8}$

Dalam kenyataan diseluruh Indonesia tanah hak, baik berasal dari Hak Milik, HGU, HGB dan lain sebagainya yang dalam penggunaannya sampai menimbulkan konflik dan sengketa hak atas tanah berhubung adanya penelantaran tanah. Kondisi tersebut sudah sangat meresahkan masyarakat, karena berdampak merugikan kepentingan rakyat

\footnotetext{
6 Ibid., hlm.84

Ibid., hlm.85.

${ }^{8}$ Ibid., hlm.86.
} 
banyak jika penelantaran itu dilakukan oleh perseorangan/badan hukum sebagai penerima hak. Terlebih penelantaran tanah dilakukan oleh pemerintah sendiri.

Seperti yang diketahui, bahwa dalam pemberian hak atas tanah oleh Negara kepada perorangan/badan hukum ini dimaksudkan agar masyarakat dapat menggunakan, mengusahakan tanah untuk mencapai kecukupan dibidang ekonomi, kesejahteraan atau kemakmuran. Agar tujuan tersebut dapat tercapai, tentunya perlu dimengerti dan difahami oleh setiap subyek hukum baik itu pemerintah, perorangan maupun badan hukum bahwa setiap penguasaan atas tanah berisikan serangkaian wewenang, kewajiban dan atau larangan bagi pemegang haknya untuk berbuat sesuatu mengenai tanah yang di haki.

Misalnya, Hak Milik, memberikan wewenang untuk menggunakan tanah yang di haki tanpa batas waktu penggunaan tanahnya. Demikian juga Hak Guna Usaha memberikan wewenang menggunakan sesuai dengan peruntukannya (Pasal 28 UUPA), penggunaan dibatasi dengan ketentuan waktu. ${ }^{9}$

Setiap hak atas tanah berarti memberikan kewenangan kepada pemegang hak untuk mempergunakan tanah yang dihaki, dan ini merupakan kewenangan umum. Artinya semua pemegang hak mempunyai kewenangan itu. Namun setiap kewenangan itu ada batasnya, yang secara keilmuan diajarkan melalui ajaran penyalahgunaaan hak $^{10}$

Pembatasan dalam penggunaan hak dapat diketahui dari sifat dan tujuan daripada haknya. Misalnya, HGB tidak dipergunakan untuk usaha pertanian. Karena hak tersebut disediakan khusus bagi penyedia dan tempat bangunan

Berdasarkan uraian di atas dapat dijelaskan bahwa Tanah PT. Inhutani di Kabupaten Nunukan, Kecamatan Nunukan, Kelurahan Nunukan Uatara merupakan Tanah negara yang dikuasai oleh PT. Inhutani sebagai

\footnotetext{
${ }^{9}$ Ibid., hlm.126
}

${ }^{10}$ Ibid., hlm.127.
Kontraktor Eksploitasi dan Industri Hutan Sesuai Peraturan Pemerintah Nomor 32 Tahun 1974, Akte Pendirian (Akte Notaris Kartini Mulyadi, SH) Nomor 77 tanggal 12 Nopember 1975, dan Akte Perubahan Anggaran Dasar terakhir (Notaris Nanda Fauz Iwan, SH K.Kn) Nomor 13 tanggal 12 Agustus 2008. Tanah PT.inhutani di kabupaten Nunukan, Kecamtan Nunukan, Kelurahan Nunukan Utara merupakan Tanah Negara yang terdaftar sebagai aset negara di Kementerian Keuangan yang dikuasai oleh PT. inhutani dengan status Hak Guna Usaha. Dengan demikian tidak dibenarkan adanya hak baru di atas hak Guna Usaha tanpa ada persetujuan dari pihak pemegang hak Guna Usaha atas tanah PT. Inhutani. Tidak mungkin ada Hak milik, HGB, Hak Pakai atau hak atas tanah lainnya di atas tanah Hak Guna Usaha tanpa ada persetujuan dari pemegang Hak. Jika terjadi hal yang demikian maka timbullah apa yang disebut dengan tumpang tindih hak atas tanah. Dan yang bertanggung jawab dalam kasus demikian adalah Pemerintah dan Badan pertanahan Nasional.

\section{PT. Inhutani (Persero) sebagai Badan Usaha Milik Negara}

Pengaturan Badan Usaha Milik Negara saat ini sudah dibuat pengaturannya secara khusus ke dalam suatu Undang-undang, yakni UU Nomor 19 Tahun 2003 Tentang Badan Usaha Milik Negara. Memperhatikan sifat-sifat dasar usaha Badan Usaha Milik Negara, yakni memupuk keuntungan dan melaksanakan kemanfaatan umum, maka dalam Undang-undang tersebut Badan Usaha Milik Negara disederhanakan ke dalam dua bentuk saja yaitu Perusahaan Perseroan (Persero) yang bertujuan memupuk keuntungan dan sepenuhnya tunduk pada ketentuan Undang-Undang Nomor 40 Tahun 2007 Tentang Perseroan Terbatas, dan Perusahaan Umum (Perum) yang dibentuk oleh pemerintah untuk melaksanakan usaha sebagai implementasi kewajiban pemerintah guna menyediakan barang dan jasa tertentu untuk memenuhi kebutuhan masyarakat. 
Pasal 9 Undang-undang Badan Usaha Milik Negara dipertegas bahwa BUMN terdiri atas Persero dan Perum. Di dalam penjelasan umum Undang-undang Badan Usaha Milik Negara tersebut dikatakan lahirnya undang-undang tersebut, diharapkan dapat mengoptimalkan peran BUMN dan mempertahankan keberadaannya dalam perkembangan ekonomi dunia yang semakin terbuka dan kompetitif. Terhadap BUMN perlu ditumbuhkan budaya korporasi dan profesionalisme yang antara lain melalui pembenahan pengurusan dan pengawasannya yang didasarkan prinsip-prinsip tata kelola perusahaan yang baik (good corporate governance).

Berdasarkan Pasal 11 Undang-undang Badan Usaha Milik Negara dikatakan bahwa terhadap BUMN Persero berlaku prinsipprinsip perseroan terbatas. Kemudian, pengertian perseroan terbatas dalam Undang-undang Perseroan Terbatas, adalah merupakan badan hukum yang didirikan berdasarkan perjanjian. Hal ini membawa konsekuensi terhadap BUMN Persero adalah juga merupakan badan hukum yang didirikan berdasarkan perjanjian yang tunduk pada ketentuan UU Nomor 1 Tahun 1995 tentang Perseroan Terbatas, yang sudah diperbaruhi dengan UU No.40 Tahun 2007.

BUMN Persero sebagai salah satu bentuk badan usaha yang tujuannya mencari untung adalah badan hukum yang terpisah dan memiliki tangung jawab yang terpisah pula, walaupun dibentuk dan modalnya berasal dari keuangan negara dan kerugian satu transaksi atau kerugian dalam badan hukum tersebut tidak dapat dikategorikan sebagai kerugian keuangan negara karena negara telah berfungsi sebagai badan hukum privat dan terhadap badan hukum tersebut berlaku juga ketentuan Undang-undang Perseroan Terbatas

Pengertian barang milik negara berdasarkan rumusan Pasal 1 angka 10 dan angka 11 Undang-undang Nomor 1 Tahun 2004 tentang Perbendaharaan Negara. Atas dasar pengertian tersebut lingkup barang milik negara disamping berasal dari pembelian atau perolehan atas beban Anggaran Pendapatan dan Belanja Negara juga berasal dari perolehan lainnya yang sah.

Selanjutnya, dalam Peraturan Pemerintah Nomor 27 Tahun 2014 tentang Pengelolaan Barang Milik Negara/Daerah, pengertian barang milik negara yang berasal dari perolehan lainnya yang sah diperjelas lingkupnya menjadi barang yang diperoleh dari hibah/sumbangan/sejenisnya, diperoleh sebagai pelaksanaan perjanjian/kontrak, diperoleh berdasarkan ketentuan undangundang dan diperoleh berdasarkan putusan pengadilan yang telah memperoleh kekuatan hukum tetap

Dimana tidak termasuk dalam pengertian barang milik negara adalah barang-barang yang dikuasai dan dimiliki oleh :

a. Pemerintah Daerah (sumber dananya berasal dari APBD termasuk yang sumber dananya berasal dari APBN tetapi sudah diserahterimakan kepada Pemerintah Daerah).

b. Badan Usaha Milik Negara/Badan Usaha Milik Daerah yang terdiri : (1) Perusahaan Perseroan, dan (2) Perusahaan Umum

\section{Asset PT. BUMN (Persero) Bukan Termasuk Kekayaan Negara}

Pasal 1 ayat (2) UU No.19 Tahun 2003 tentang Badan Usaha Milik Negara menyatakan bahwa Perusahaan Persero, yang selanjutnya disebut Persero, adalah BUMN yang berbentuk perseroan terbatas yang modalnya terbagi dalam saham yang seluruh atau paling sedikit 51\% (lima puluh satu persen) sahamnya dimiliki oleh Negara Republik Indonesia yang tujuan utamanya mengejar keuntungan. Selanjutnya Pasal 11 menyebutkan terhadap Persero berlaku segala ketentuan dan prinsip-prinsip yang berlaku bagi perseroan terbatas sebagaimana diatur dalam Undang-Undang No.1 Tahun 1995 tentang Perseroan Terbatas, yang sudah diperbaruhi dengna UU No.40 Tahun 2007. ${ }^{11}$

${ }^{11}$ Erman Rajagukguk.(2006). Pengertian Keuangan Negara dan kerugian Negara, disampaikan pada diskusi 
Undang-undang BUMN bersifat khusus (lex-spesialis) sehingga pengelolaan asset BUMN, termasuk piutang BUMN, harus didasarkan pada prinsip-prinsip korporasi. Penafsiran itu senada dengan fatwa MA Nomor WKMA/Yud/20/VIII/2006 tanggal 16 Agustus 2006 tentang revisi atas PP Nomor 14 Tahun 2005 yang berkaitan dengan pengelolaan piutang BUMN. ${ }^{12}$

Menurut fatwa MA itu, piutang BUMN bukan termasuk piutang negara, karena asset BUMN tidak lagi tergolong sebagai asset negara. berdasarkan fatwa MA itu Presiden Susilo Bambang Yudhoyono kemudian menerbitkan PP Nomor 33 Tahun 2006 tentang revisi atas PP Nomor 14 Tahun 2005 tentang tata cara Penghapusan Piutang Negara/Daerah. Sesuai PP Nomor 33 Tahun 2006, maka sejak 6 Oktober 2006 penelolaan piutang BUMN tidak lagi ditangani PUPN, tetapi cukup ditangani setiap BUMN. ${ }^{13}$

Karakteristik suatu badan hukum adalah pemisahan harta kekayaan badan hukum dari harta kekayaan pemilik dan pengurusnya. Dengan demikian suatu Badan Hukum yang berbentuk Perseroan Terbatas memiliki kekayaan yang terpisah dari kekayaan Direksi (sebagai pengurus), Komisaris (sebagai pengawas), dan Pemegang Saham (sebagai pemilik). Begitu juga kekayaan yayasan sebagai Badan Hukum terpisah dengan kekayaan Pengurus Yayasan dan Anggota Yayasan, serta Pendiri Yayasan. Selanjutnya kekayaan Koperasi sebagai Badan Hukum terpisah dari kekayaan Pengurus dan Anggota Koperasi. ${ }^{14}$

BUMN yang berbentuk Perum juga adalah Badan Hukum. Pasal 35 ayat (2) Undang-Undang No. 19 Tahun 2003 tentang Badan Usaha Milik Negara menyatakan, Perum memperoleh status Badan Hukum sejak diundangkannya Peraturan Pemerintah tentang pendiriannya. Berdasarkan Pasal 7 ayat (6) Undang-Undang No. 1 Tahun 1995

\footnotetext{
publik Komisi Hukum Nasional (KHN) RI, Jakarta.

2 Serfianto DP dan Iswi Hariyani.(2007). Bisakah BUMN Dipailitkan, Media Indonesia.

${ }^{13}$ Ibid.

${ }^{14}$ Erman Rajagukguk, Loc.cit.
}

tentang Perseroan Terbatas yang sudah diperbaruhi denngan UU, BUMN Persero memperoleh status Badan Hukum setelah akte pendiriannya disahkan oleh Menteri Kehakiman (sekarang Menteri Hukum dan HAM).

Berdasarkan hal-hal tersebut diatas kekayaan BUMN Persero maupun kekayaan BUMN Perum sebagai Badan Hukum bukanlah kekayaan Negara. ${ }^{15}$ Sebenarnya tidak ada yang salah dengan perumusan mengenai keuangan Negara dalam penjelasan Undang-Undang No.31 Tahun 1999 tentang Tindak Pidana Korupsi yang menyatakan:

Keuangan negara yang dimaksud adalah seluruhkekayaan negara dalam bentuk apapun, yang dipisahkan atau yang tidak dipisahkan, termasuk didalamnya segala bagian kekayaan negara dan segala hak dan kewajiban yang timbul karena: (a) berada dalam penguasaan, pengurusan, dan pertanggung jawaban pejabat lembaga Negara, baik di tingkat pusat maupun di daerah; (b) berada dalam penguasaaan, pengurusan, dan pertanggung jawaban Badan Usaha Milik Negara/Badan Usaha Milik Daerah, yayasa, badan hukum dan perusahaan yang menyertakanmodal negara, atau perusahaan yang menyertakan modal pihak ketiga berdasarkan perjanjian dengan Negara.

Maksud "kekayaan negara yang dipisahkan" dalam Badan Usaha Milik Negara (BUMN) secara fisik adalah berbentuk saham yang dipegang oleh negara, bukan harta kekayaan Badan Usaha Milik Negara (BUMN) itu.37 Pasal 4 ayat (1) Undang-Undang BUMN: menyatakan bahwa modal BUMN berasal dari kekayaan negara yang dipisahkan. Penjelasan pasal 4 ayat (1) Yang dimaksud dengan dipisahkan adalah pemisahan kekayaan negara dari Anggaran Pendapatan dan Belanja Negara untuk dijadikan penyertaan modal negara pada BUMN untuk selanjutnya pembinaan dan pengelolaannya tidak lagi didasarkan pada sistem Anggaran Pendapatan dan Belanja Negara. Asset BUMN bukan

\footnotetext{
${ }^{15}$ Ibid., hlm.3.
} 
merupakan Kekayaan Negara karena modal BUMN berasal dari kekayaan Negara yang dipisahkan (sumber lain dari APBN/APBD, misalkan hasil kapitalisasi cadangan dan kapitalisasi pinjaman.) Namun apabila modal BUMN berasal dari APBN/APBD maka aset BUMN tersebut dikategorikan sebagai kekayaan negara. Berdasarkan Pasal 3 PP Nomor 11 Tahun 2010 yang tidak termasuk obyek penertiban adalah tanah yang dikuasai pemerintah baik secara langsung maupun tidak langsung dan sudah berstatus maupun belum berstatus sebagai Barang Milik Negara/Daerah. Karena modal BUMN berasal dari kekayaan negara yang dipisah maka kekayaan BUMN bukan berstatus Barang Milik Negara/Daerah.

Hak penguasaan atas tanah berisi serangkaian wewenang, kewajiban, dan atau larangan bagi pemegang haknya untuk berbuat sesuatu mengenai tanh yang di hakinya. Sesuatu yang boleh, wajib atau dilarang untuk diperbuat, yang merupakan isi hak penguasaan itulah yang menjadi kriteria atau tolo ukur pembeda di antara hak-hak penguasaan atas tanah yang diatur dalam Hukum Tanah.

Pengertian penguasaan dapat dipakai dalam arti fisik, juga dalam arti yuridis. Juga beraspek privat dan publik. Penguasaaan dalam arti yuridis adalah penguasaan yang dilandasi hak, yang dilindungi oleh hukum dan pada umumnya memberi kewenangan kepada pemegang hak untuk menguasai secara fisik tanah yang dihaki, misalnya pemilik tanah mempergunakan atau mengambil mamfaat daritanahyang dihaki, tidak diserahkankepada pihak lain. Ada juga penguasaan yuridis, yang biarpun memberikan kewenangan untuk menguasai tanah yang dihaki secara fisik, pada kenyataanya penguasaan fisiknya dilakukan oleh pihak lain, misalnya seseorang yang memiliki tanah tidak mempergunakan tanahnya sendiri akan tetapi disewakan kepada pihak lain, dalam hal ini secara yuridis tanah tersebut dimiliki oleh pemilik tanah akan tetapi secara fisik dilakukan oleh penyewa tanah. Ada juga penguasaan secara yuridis yang tidak memberi kewenangan untuk menguasai tanah yang bersangkutan secara fisik, misalnya kreditor (bank) pemegang hak jaminan atas tanah mempunyai hak penguasaan tanah secara yuridis atas tanah yang dijadikan agunan (jaminan), akan tetapi secara fisik penguasaan tetap ada pada pemilik tanah. Penguasaan yuridis dan fisik atas tanah tersebut diatas dipakai dalam aspek privat atau keperdataan sedang penguasaan yuridis yang beraspek publik dapat dilihat pada penguasaan atas tanah sebagaimana yang disebutkan dalam pasal 33 ayat (3) UUD 1945 dan pasal 2 UUPA.

\section{Kebijakan Pemerintah Daerah Dalam Penertiban Pemanfaatan Tanah Warga Di Wilayah Pesisir Perbatasan}

Hak Pakai atas tanah sama dengan Hak Milik, Hak Guna Usaha, dan Hak Guna Bangunan yang merupakan hak atas yang bersifat primer. Hak Pakai atas tanah berbeda dengan Hak Guna Usaha dan Hak Guna Bangunan, karena Hak Pakai mempunyai subjek yang terbanyak dibandingkan dengan hak-hak tersebut. ${ }^{16}$

Pemberian Hak Pakai atas tanah terhadap pemegang Hak Pakai tidak sama dengan pemberian hak atas tanah bagi Hak Guna Usaha dan Hak Guna Bangunan. Pemberian Hak Pakai atas tanah memiliki ciri tersendiri yang tidak akan dijumpai pada hak-hak selain Hak Pakai tersebut. Hal ini sesuai Pasal 39 Peraturan Pemerintah Nomor 40 Tahun 1996 diatur mengenai subjek yang dapat mempunyai Hak Pakai atas tanah yaitu:

a. Warga Negara Indonesia.

b. Badan hukum yang didirikan menurut hukum Indonesia dan berkedudukan di Indonesia.

c. Departemen, Lembaga Pemerintah nonDepartemen dan Pemerintah Daerah.

d. Badan-badan keagamaan dan sosial.

e. Orang-orang asing yang berkedudukan di Indonesia.

${ }^{16}$ Supriadi.(2007). Hukum Agraria, Jakarta: Sinar Grafika, hlm.118-124. 
f. Badan hukum asing yang mempunyai perwakilan di Indonesia.

g. Perwakilan negara asing dan perwakilan badan Internasional.

Sejalan dengan pemberian kepada orang atau badan hukum yang dapat menguasai tanah dengan Hak Pakai, adalah apabila pemegang Hak Pakai tidak lagi memenuhi syarat sebagaimana diatur dala Pasal 39 ayat 1 di atas, wajib dalam satu tahun pemegang hak melepaskan atau mengalihkan hak itu pada pihak lain yang memenuhi syarat Pasal 40 (ayat 1). Oleh karena itu, apabila satu tahun Hak Pakai itu tidak dilepaskan atau dialihkan, hak tersebut hapus karena hukum dengan ketentuan hak-hak pihak lain yang terkait di atas tanah tersebut tetap diperhatikan (Pasal 48 ayat 2$).{ }^{17}$

Berkaitan dengan ketentuan Pasal 40 di atas, maka tanah yang dapat diberikan dengan Hak Pakai adalah:

a. Tanah negara

b. Tanah Hak Pengelolaan

c. Tanah Hak Milik Pasal 41 ayat (1)

Sementara Hak Pakai atas tanah negara pemberiannya dilakukan dengan keputusan dari menteri atau pejabat yang berwenang, sedangkan Hak Pakai atas tanah Hak Pengelolaan diberikan dengan keputusan pemberian oleh menteri atau pejabat yang ditunjuk itu berdasarkan usul pemegang Hak Pengelolaan. Tata cara dan syarat pemberian hak atas tanah negara dan Hak Pengelolaan diatur lebih lanjut dengan Keputusan Presiden Pasal 42 ayat (1, 2,dan 3). Pemberian Hak Pakai atas tanah baik pada tanah negara, maupun Hak Pengelolaan tetap harus didaftar di Kantor Pertanahan dalam buku tanah, sebagai tanda bukti hak kepada pemegang Hak Pakai diberikan setifikat hak atas tanah Pasal 43 ayat $(1,2$, dan 3$)$. Sementara itu, bagi Hak Pakai atas tanah Milik terjadi dengan pemberian tanah oleh pemegang Hak Milik yang dibuat oleh Pejabat Pembuat Akta Tanah. Pemberian Hak Pakai tanah Milik wajib didaftarkan dalam buku tanah pada Kantor Pertanahan. Oleh karena itu, Hak Pakai atas tanah Hak Milik mengikat pihak ketiga sejak saat pendaftarannya di Kantor Pertanahan. Tata cara pemberian dan pendaftaran Hak Pakai atas tanah Hak Milik diatur lebih lanjut dengan Keputusan Presiden (Pasal 43 ayat (1, 2, dan 3).

Hanya saja ada beberapa catatan mengenai Hak Pakai berdasarkan permohonan hak dengan subjek hak atas tanah, yang terdiri dari orang perorang dan badan hukum. Akan tetapi UUPA masih meninggalkan banyak pekerjaan rumah, dalam pembentukan peraturan perundangundangan yang merupakan peraturan pelaksanaan UUPA. Pada umumnya UUPA tidak dilengkapi dengan pemikiran yang tuntas terhadap peraturan pelaksanaannya. Diperlukan upaya terus menerus untuk melakukan penemuan hukum dalam rangka pembangunan hukum tanah yang bertanggung jawab.

Jangka waktu yang terdapat pada Hak Pakai atas tanah, baik yang dikuasai oleh pemegang Hak Pakai yang terjadi atas tanah negara atau Hak Milik berbeda dengan jangka waktu pada Hak Guna Usaha dan Hak Guna Bangunan. Dalam Pasal 45 Peraturan Pemerintah Nomor 40 Tahun 1996 dinyatakan bahwa:

Hak Pakai diberikan untuk waktu paling lama dua puluh tahun dan dapat diperpanjang untuk jangka waktu paling lama dua puluh tahun atau diberikan untuk jangka waktu yang tidak ditentukan selama tanahnya dipergunakan untuk keperluan tertentu. sesudah jangka waktu pakai atau perpanjangannya habis, kepada pemegang hak dapat diberikan pembaruan Haka Pakai atas tanah yang sama (ayat 1 dan 2).

Sejalan dengan ketentuan Pasal 45 ayat (1) dan (2) di atas, maka khusus untuk pemberian jangka waktu untuk keperkuan tertentu dalam Pasal 45 ayat (3) dinyatakan bahwa: 
Hak Pakai yang diberikan untuk jangka waktu yang ditentukan selama dipergunakan untuk keperluan tertentu diberikan kepada: (a) departemen, lembaga pemerintah nondepartemen dan pemerintah daerah; (b) perwakilan negara asing dan pewakilalan badan internasional; (c) badan keagamaan dan badan sosial.

Khusus untuk Hak Pakai atas tanah negara dapat diperpanjang atau diperbarui tas permohonan pemegang hak, jika memenuhi syarat:

a. Tanahnya masih dipergunakan dengan baik sesuai dengan sifat dan tujuan pemberian hak tersebut.

b. Syarat-syarat pemberian hak tersebut dipenuhi dengan oleh pemegang hak.

c. Pemegang hak masih memenuhi syarat pemegang hak sebagaimanadimaksudusul pemegang Hak Pengelolaan. ${ }^{18}$

Berkaitan dengan jangka waktu Hak Pakai baik yang berasal dari tanah negara dan tanah Hak Milik, maka khusus untuk Hak Pakai atas tanah Hak Pengelolaan dapat diperpanjang atau diperbarui atas usul pemegang Hak Pengelolaan. Permohonan perpanjangan jangka waktu HakPakai Pembaruan diajukan selambatlambatnya dua tahun sebelumberakhirnya jangka waktuHak Pakai tersebut. Dengan demikian, perpanjangan atau pembaruan Hak Pakai dicatat dalam buku tanah pada Kantor Petanahan. Oleh karna itu, tata cara permohonan perpanjangan atau pembaruan Hak Pakai dan persyaratannya diatur lebih lanjut dengan Keputusan Presiden (Pasal 47 PP Nomor 40 Tahun 1996).

Sejalan dengan perpanjangan jangka waktu terhadap Hak Pakaiyang diperuntukan bagi penanaman modal memiliki tata cara dan syrat tersendiri. Hal ini sesuai dengan Pasal 48 Peraturan Pemerintah Nomor 40 Tahun 1996 yang menyatakan bahwa:

Untuk kepentingan penananaman modal, permintaan perpanjangan dan pembaruan Hak Pakai dapat dilakukan sekaligus dengan pembayaran uang pemasukan yang

\footnotetext{
18 Ibid. hlm.111.
}

ditentukan untuk itu pada saat pertama permohonan Hak Pakai. Dalam hal uang pemasukan telah dibayar sekaligus, perpanjangan atau pembayaran Hak Pakai hanya dikenakan biaya administrasi yang besarnya ditetapkan oleh menteri setelah mendapat persetujuan dari Menteri Keuangan.

Sementara itu, Hak Pakai atas tanah Hak Milik diberikan untuk jangka waktu paling lama dua puluh lima tahun dan tidak diperpanjang. Namun atas kesepakatan antar pemegang Hak Pakai dengan pemegang Hak Milik, Hak Pakai atas tanah Hak Milik dapat diperbarui dengan pemeberian Hak Pakai baru dengan akta yang dibuat oleh Pejabat Pembuat Akta Tanah dan hak tersebut wajib didaftarkan (pasal 49).

Sama seperti halnya dengan hakhak atas tanah lainnya yang menyangkut mengenai jangka waktu, dalam Pasal 45 Peraturan Pemerintah Nomor 40 Tahun 1996 telah diatur mengenai jangka waktu pemberian Hak Pakai atas tanah, yaitu: diberikan untuk jangka waktu paling lama dua puluh lima tahun dan dapat diperpanjang untuk jangka waktu paling lama dua puluh tahun atau diberikan untuk jangka waktu yang tidak ditentukan selama tanahnya dipergunakan untuk keperluan tertentu (Pasal 45 ayat 1 ).

Menyangkut pemberian Hak Pakai atas tanah yang tidak ditentukan jangka waktunya kepada PT. Inhutani di kabupaten Nunukan, kecamatan Nunukan, kelurahan Nunukan Utara karena untuk keperluan tertentu , selama tanahnya dipergunakan untuk keperluan tertentu yaitu Industri Pengelolaan Hutan dan Kayu. Namun pada kenyataannya PT.inhutani yang berada di Nunukan, kecamatan Nunukan, kelurahan Nunukan, tidak lagi secara langsung mengelola Hutan dan kayu melainkan, hanya berkantor dan mengontrol asset-aset PT. inhutani yang masih ada, dikarenakan daerah Pesisir kabupaten nunukan, kecamatan nunukan, kelurahan nunukan utara, tidak lagi hutan melainkan sudah 
menjadi permukiman warga. Sabagian di antarannya digunakan untuk Fasilitas Umum seperti Puskesmas dan Tempat Ibadah. Hal ini sesuai dengan ketentuan Pasal 45 ayat (3) Peraturan Pemerintah Nomor 40 tahun 1996, disebutkan sebagi berikut:

1. Departemen, lembaga pemerintah nondepartemen dan pemerintah daerah.

2. Perwakilan negara asing dan pewakilalan badan internasional.

3. Badan keagamaan dan badan social

\section{a. Bangunan di atas Tanah PT.Inhutani daerah Pesisir}

Pihak PT Inhutani saat ini kembali membuka peluang untuk membicarakan harga tanah milik PT Inhutani yang akan dilepas kepada masyarakat dan Pemkab Nunukan. Pembicaraan mengenai rencana pembebasan lahan milik PT Inhutani di Pulau Nunukan sebelumnya sudah berjalan sejak 2009 lalu. Namun hingga kini, rencana itu masih mengalami kebuntuan. Warga menolak harga yang ditawarkan direksi PT Inhutani yakni berkisar antara Rp 227.000 hingga $\mathrm{Rp}$ 957.000 permeter persegi. "Ini bukan jual beli properti. Mari kita duduk sama-sama untuk membahas masalah harga ini. Ada janda yang punya tanah hingga 400 meter. Berapa yang harus dia bayar untuk mendapatkan tanah tersebut? Saya miris karena wanita itu mengatakan, jangankan untuk bayar tanah, untuk makan saja susah," kata Imral Gusti dari Forum Perjuangan Tanah Untuk Rakyat, saat rapat dengar pendapat (RDP) antara masyarakat, pihak PT Inhutani dan DPRD Kabupaten Nunukan saat itu. Direktur Utama PT Inhutani, Irsyal Yasman mengatakan, harga tanah yang akan dibebaskan di Nunukan ditetapkan para pemegang saham. "Yang kami lakukan soal penetapan harga itu sudah sesuai prosedur. Apa keputusan menteri, itulah keputusan pemegang saham. Setelah itu Sekretaris Menteri BUMN Sayid Midu untuk mengundang DPRD Nunukan dan Pemda Nunukan ke Jakarta," ujarnya. Dalam persoalan tanah ini, PT Inhutani mengaku berhati-hati mengikuti prosedur yang berlaku. Sebab tidak sedikit jual beli aset BUMN berujung pada kasus hukum. Sebagian besar tanah aset PT Inhutani di Pulau Nunukan telah dikuasai warga untuk pemukiman. Sebagian diantaranya digunakan untuk fasilitas umum seperti puskesmas dan rumah ibadah. Persoalan penguasaan aset Inhutani ini sebenarnya sudah terjadi sejak tahun 1970-an silam saat perusahaan BUMN itu beroperasi di Nunukan. Sebagian warga bekerja di Inhutani dan menempati rumah-rumah dinas milik perusahaan. "Saat itu aktivitas masih normal dan tidak ada masalah. Sekitar tahun 1980-an baru mulai muncul masalah ketika mereka ada yang pensiun. Dan ini tidak pernah diselesaikan karena peliknya persoalan. Belakangan setelah Nunukan menjadi daerah otonom, Pemkab Nunukan juga memerlukan lahan untuk pengembangan kota. Namun kepastian hukum lahan tidak ada, karena masih berada dibawah kepemilikan PT Inhutani. Dengan difasilitasi Sekretaris Menteri BUMN, persoalan ini disampaikan kepada pemegang saham. Setelah keluar persetujuan lewat surat Menteri BUMN Nomor S.314/MBU/3009 tanggal 11 Mei 2009, kemudian ditentukan harga jual yang berdasarkan pada kajian tim independen. "Kalau tanah ini bisa dijual, sebenarnya prosesnya sudah sangat berhasil. Karena selama ini tidak pernah kita menjual aset. Karena di BUMN soal jual menjual masih alergi, ini selalu berujung hukum," katanya. Untuk pemindahtanganan aset BUMN bukanlah persoalan yang mudah. Untuk kepentingan umum tidak boleh aset tersebut dihibahkan. Namun lahan tersebut dapat dipinjampakaikan hingga batas waktu yang tidak ditentukan selama tidak berubah fungsinya. Selama tanah-tanah dengan status hak guna bangunan (HGB) itu masih dimiliki PT Inhutani, tentu aset itu akan selalu tercatat di neraca perusahaan yang diaudit setiap tahun. Selain itu pihak perusahaan harus mengeluarkan beban biaya setiap tahunnya untuk pembayaran pajak bumi dan bangunan (PBB) serta pengamanan. 
Sebagaimana di jelaskan di atas bahwa tanah inhutani adalah merupakan hak Pakai atas tanah negara oleh PT. inhutani. Jadi PT. inhutani adalah pemegang hak Pakai. Dengan demikian secara yuridis penguasaan Tanah inhutani ada pada PT. Inhutani Sehingga di atas tanah inhutani tidak dimungkinkan terbit lagi hak baru. Namun secara fisik tanah inhutani milik PT. inhutani di kabupaten nunukan, kecamatan nunukan, kelurahan nunukan utara setelah tidak produktif sebagaian besar dikuasai oleh pihak lain. Hal ini terbukti dengan data tahun 2015 - Hingga Sekarang, telah berdiri \pm 7.049 bangunan. Hal ini menimbulkan ketidak pastian hukum terhadap hak atas tanah inhutani baik bagi PT. Inhutani maupun kepada pemilik bangunan.

Terkait dengan alas hak bangunan di atas tanah inhutani daerah pesisir, menurut Tri Hastuti Nursanti,S.E ${ }^{19}$ ada yang sama sekali tidak memiliki alas hak, dan ada pula yang memiliki sertipikat Hak Milik yang dikeluarkan oleh Pemerintah Kabupaten Bulungan ketika Nunuakan masih merupakan bagian dari Kabupaten Bulungan, Khusus perbuatan meneribitkan Sertikat Hak Milik diatas Hak Pakai Milik PT Inhutani adalah perbuatan melanggar hukum yang dilakukan oleh Administratur Negara. Sertipikat Hak atas tanah sebagai bukti telah didaftarkannya hak tersebut di Badan Pertanahan Nasional. Namun dalam konteks penerbitan sertipikat Hak milik di atas tanah Hak Pakai inhutani dapat dipastikan telah terjadi cacat hukum dalam proses penerbitannya. Dalam kasus ini pemerintah daerah yang menerbitkan Sertipikat dapat digugat ke PTUN dengan maksud membatalkan putusan TUN yakni sertipikat Hak milik. Telah terjadi tumpang tindih hak atas tanah.

Jika para pemilik bangunan telah menguasai tanah inhutani dengan mendirikan bangunan rumah tempat tinggal permanen dan tempat usaha tanpa didasari alas hak, juga tidak dapat membuktikan perolehan dan

${ }_{19}$ Tri Hastuti Nursanti, Plt Lurah, Kecamatan Nunukan, kelurahan Nunukan Utara Wawancara tanggal 02 Maret 2018 . kepemilikannya dapat dikategorikan telah melakukan perbuatan melawan hukum yang merugikan PT. Inhutani, akan tetapi paada dasaranya masyarakat yang memilki tempat tingggal selalu melakukan kewajiban mereka untuk membayat Pajak Bumu Bangunan (PBB).

\section{b. Hak Guna Bangunan sebagai Solusi Hukum bagi pemilik bangunan di atas Tanah inhutani}

Terkait dengan banyaknya bangunan yang berdiri di atas Tanah inhutani tanpa alas yang jelas, maka menurut penulis solusi hukum yang dapat memberikan perlindungan hukum kepada pemilik bangunan adalah mengajukan permohonan HGB dengan mimintah persetujuan dari PT.Inhutani. Alasannya adalah bahwa HGB dibatasi waktu yakni 20 tahun dan dapat diperpanjang paling lama 30 tahun, Dan setelah itu maka tanah tersebut kembali kepada pemegang hak. Karena Tanah inhutani merupakan aset negara yang penguasaannya dibawah PT. Inhutani sebagai Badan Usaha Milik Negara, sehingga tidak memungkinkan adanya hak milik di atas tanah inhutani. Kalau hal ini sampai terjadi, berarti telah terjadi perbuatan melawan hukum yang merugikan negara berupa tindak pidana penggelapan aset negara. Dengan diberikannya HGB, pemilik bangunan memperoleh kepastian hukum atas bangunan, dilain pihak aset negara berupa tanah inhutani tidak hilang. Hal ini sesuai dengan prinsip pemisahan horisontal

Prosedur pengajuan permohonan HBG adalah sebagai berikut:

1. Permohonan HGB diajukan kepada menteri melalui kepala kantor pertanahan yang daerah kerjanya meliputi letak tanah yang bersangkutan. Yang dimaksud sebagai menteri adalah menteri yang bertanggung jawab di bidang agraria/pertanahan. Kantor pertanahan adalah Badan Pertanahan Nasional di tingkat kabupaten/kota (Kantor Pertanahan).

2. Setelah berkas diterima, Kepala Kantor Pertanahan kemudian: 
a. Memeriksa dan meneliti kelengkapan data yuridis dan data fisik;

b. Mencatat pada formulir isian;

c. Memberitahukan tanda terima berkas permohonan sesuai formulir isian. Memberitahukankepadapemohonuntuk membayar biaya untuk menyelesaikan permohonan tersebut dengan rinciannya sesuai ketentuan peraturan perundangundangan yang berlaku.

3. Kepala Kantor Pertanahan meneliti kelengkapan dan kebenaran data yuridis dan data fisik dan memeriksa kelayakan permohonan tersebut dapat atau tidaknya dikabulkan.

4. Dalam hal tanah yang dimohon belum ada surat ukurnya, Kepala Kantor Pertanahan memerintahkan Kepala Seksi Pengukuran dan Pendaftaran Tanah untuk mempersiapkan surat ukur atau melakukan pengukuran.

5. Selanjutnya Kepala Kantor Pertanahan memerintahkan kepada:

a. Kepala seksi hak atas tanah atau petugas yang ditunjuk untuk memeriksa permohonan hak terhadap tanah yang sudah terdaftar, peningkatan, perpanjangan atau pembaharuan hak atas tanah dan terhadap tanah yang data yuridis atau data fisiknya telah cukup untuk mengambil keputusan yang dituangkan dalam risalah pemeriksaan tanah; atau

b. Tim Penelitian Tanah untuk memeriksa permohonan hak terhadap tanah yang belum terdaftar yang dituangkan dalam berita acara; atau

c. Panitia Pemeriksa Tanah A untuk memeriksa permohonan hak terhadap tanah selain yang diperiksa sebagaimana dimaksud pada huruf (a) dan huruf (b), yang dituangkan dalam risalah pemeriksaan tanah.

6. Dalam hal data yuridis dan data fisik belum lengkap, Kepala Kantor Pertanahan memberitahukan kepada pemohon untuk melengkapinya.
7. Setelah mempertimbangkan pendapat Kepala Seksi Hak Atas Tanah atau pejabat yang ditunjuk atau Tim Penelitian Tanah atau Panitia Pemeriksa Tanah A, Kepala Kantor Pertanahan menerbitkan keputusan pemberian Hak Guna Bangunan atas tanah yang dimohon atau keputusan penolakan yang disertai dengan alasan penolakannya. Hubungan hukum yang menjadi dasar pemberian hak atas tanah oleh pemegang hak pengelolaan kepada pihak ketiga ditetapkan dalam surat perjanjian penggunaan tanah (SPPT). Dalam Praktik, SPPT tersebut dapat disebut dengan nama lain, misalnya: Perjanjian Sehubungan dengan penyerahan bagian tanah hak pengelolaan PT. inhutani kepada pihak ketiga, persyaratan-persyaratan tersebut dituangkan dalam bentuk perjanjian yang diadakan oleh para pihak yang juga merupakan hukum bagi hubungan konkret yang bersangkutan (Pasal 1338 KUHPerdata) tetapi ada pembatasannya, yaitu khusus dibidang hukum tanah, sepanjang perjanjian yang diadakan itu tidak melanggar atau bertentangan dengan ketentuan-ketentuan UUPA. ${ }^{20}$

Berdasarkan perjanjian tertulis/surat penyerahan yang dibuat antara pemegang hak pengelolaan dengan pihak ketiga, maka pihak ketiga dapat mengajukan permohonan untuk memperoleh sesuatu hak atas tanah hak pengelolaan tersebut kepada Kantor Pertanahan setempat. Dalam perjanjian antara pemegang hak pengelolaan dan pihak ketiga harus dibuat hak apa yang diberikan oleh pemegang hak pengelolaan, yaitu apakah hak guna Bangunan atau Hak Lainnya, yang bisa memberikan kepastian hukum atas Hak Tanah Masyarakat.

\section{DAFTAR PUSTAKA}

Aminuddin salle dkk.(2010). Hukum Agraria, AS.

Harsono, Budi, (2005). Hukum Agraria Indonesia: Sejarah Pembentukan Undang- Undang Pokok Agraria,

${ }^{20}$ Boedi Harsono, Op.Cit., p.268. 
Isi dan Pelaksanaannya. Jakarta: Djambatan.

Hasni.(2008). Hukum Penataan Ruang dan Penatagunaan Tanah, Jakarta: Rajawali Press.

Hatta, Mohammad. (2005). Hukum Tanah Nasional, Yogyakarta: Media Abadi.

Muljadi dan Gunawan Widjaja.(2008). HakHak Atas Tanah, Jakarta: Prenada Media.

Maria S.W.Sumardjono.(2005). kebijakan Pertanahan Antara Regulasi dan Implementasi, Jakarta: Buku Kompas.

Patittingi, Farida. (2012). Dimensi Hukum Pulau-Pulau Kecil di Indonesia, Yogyakarta: Rangkang Education.

Rajagukguk Erman.(2006). Pengertian Keuangan Negara dan kerugian Negara, disampaikan pada diskusi publik Komisi Hukum Nasional (KHN) RI, Jakarta 26 Juli 2006.

Rokhmin Dahuri.(2004). Pengelolaan Sumber Daya Wilayah Pesisir Dan Laut Secara Terpadu, Jakarta: Pradnya Paramita.

Serfianto DP dan Iswi Hariyani.(2007). Bisakah BUMN Dipailitkan, Media Indonesia.

Soerjono Soekanto dan Sri Mamudji.(2006). Penelitian Hukum Normatif, Jakarta: PT. Raja Grafindo Persada.

Suhariningsih.(2009). Tanah Terlantar, Jakarta: Prestasi Pusaka.

Supriadi.(2008). Hukum Agraria, Jakarta: Sinar Grafika.

Urip Santoso.(2009). Hukum Agraria dan Hak-Hak Atas Tanah, Jakarta: Kencana Prenada Media.

Yudhi Setiawan.(2009). Instrumen Hukum Campuran (gemeenschapelijkrecht) dalam Kosolidasi Tanah, Rajawali Press.
Peraturan Perundang-Undangan

Undang-Undang Dasar 1945;

Undng-undang Nomor 39 Tahun 1999 Tentang Hak Asasi Manusia;

Undang-undang Nomor 5 Tahun 1960 Tentang Pokok-Pokok Dasar Agraria.

Undang-undang Nomor 1 Tahun 2011 Tentang Perumahan dan Kawasan Permukiman.

Undang-undang Nomor 11 Tahun 2005 Tentang Pengesahan International Covenant On Economic, Social And Cultural Rights (Kovenan Internasional Tentang Hak-Hak Ekonomi, Sosial Dan Budaya).

Undang-Undang Nomor 1 Tahun 2014 Tentang Perubahan Atas UndangUndang Nomor 27 Tahun 2007 Tentang Pengelolaan Wilayah Pesisir Dan Pulau-Pulau Kecil

Undang-Undang Nomor 23 Tahun 2014 tentang Pemerintahan Daerah

Undang - Undang Nomor 19 Tahun 2003 Tentang Badan Usaha Milik Negara.

Undang-Undang Nomor 40 Tahun 2007 Tentang Perseroan Terbatas

\section{Internet}

http://kaltim.tribunnews.com/2014/02/14/ dprd-nunukan-tolak-penjualan-asetpt-inhutani.

https://kaltim.antaranews.com/berita/6506/ pemkab-nunukan-fasilitasipenyelesaian-sengketa- inhutaniwarga

https://regiona $1 . \mathrm{kompas} . \mathrm{com} /$ $\mathrm{read} / 2018 / 04 / 21 / 16093811 /$ tanahbelum-dibayar-bangunan-milikpemda-di-nunukan-dipagar-warga 